\title{
Indigenous Peoples and Their Struggle for Citizenship and Collective Identity in Indonesia
}

\author{
Triyanto Triyanto and Rima Vien Permata Hartanto \\ Faculty of Teacher Training and Education, Sebelas Maret University \\ Surakarta, Indonesia \\ try@staff.uns.ac.id
}

\begin{abstract}
One of the forms of socio-cultural pluralism of Indonesia is the existence of indigenous peoples with their customary law system. Indonesia as an archipelagic country, the number of indigenous peoples is estimated at around 40-50 million, out of more than 10,000 ethnic and sub-ethnic groups spreading throughout the inter-regional region. Indigenous peoples are anthropological entities that grow naturally on a certain part of the earth, and consist of various small primordial communities whose citizens have blood relation to each other. The existence of such indigenous peoples places them in a minority position. This sense of minority is more or less similar to the understanding of marginal society; those in a series of common life in the public space are often on the edge, or more precisely marginalized by the dominant. Indigenous peoples are very vulnerable groups in our society and the country in general. The focus of this paper is discusses the struggle for citizenship and collective identity among indigenous peoples in Indonesia. This study is theoretical using literature review method based on literature and combined with bibliographic research that focuses on the ideas contained in the theory. As conclusion that the indigenous peoples' struggle for inclusive citizenship, which requires the Government of Indonesia to legally and actually recognize and respect the status of indigenous people's citizenship in the Unitary State of the Republic of Indonesia is not yet over. It takes a pluralist approach that sees indigenous peoples as a diversity that must be maintained, so that indigenous peoples need to be guaranteed their basic rights independently to determine choices for the development of their respective communities. Therefore, the future discourse on citizenship in Indonesia is not only seen from the individual citizens, but also communal citizens who are members of indigenous communities.
\end{abstract} identity

Keywords - indigenous peoples; struggle; citizenship; collective

\section{INTRODUCTION}

The reality of the socio-political structure of Indonesian society is very plural and heterogeneous. It is because there are so many groups of micro socio-political entities formed in societies whose lives and relationships are based on selfcreated laws outside the law of their own country. One example of such a community is the indigenous peoples who existed long before Indonesia was established. The Indonesian Constitution (UUD 1945) in Article 18B verse 2 and Article 28I verse (3) expressly recognizes the existence of indigenous peoples and their traditional rights. Even though there is normative recognition of the existence and rights of indigenous peoples, the reality of the field situation is very different from what sounds from those two articles that recognize the indigenous people in the 1945 Constitution.

Therefore, the discussion on indigenous peoples is always important. It, since, involves the diversity that is the main foundation of the founding of the Republic of Indonesia as described in the expression of Bhineka Tunggal Ika and the Third Sila of Pancasila, namely Indonesian Unity (Persatuan Indonesia). Indigenous peoples and their existence have always been an interesting and often controversial topic, especially if indigenous peoples and their rights are confronted with the interests of the state or government and corporations. Most indigenous communities are poor and oppressed because of injustice and inequality in the mastery of the resources.

Various forms of injustice, including agrarian, environmental, gender, and social injustice, affect indigenous peoples as a result of state and corporate domination that led to the emergence of various forms of resistance which later developed into social movements. Polanyi referred to this movement as a "counter movement", as an effort to protect the land, labor, and resources of the commodification process [1]. According to Polanyi, counter movements are formed because people recognize the risk of destruction and develop protective measures to rebuild their lives [1]

In Indonesia, indigenous peoples' resistance to state and corporate dominance has been strengthened since the establishment of the Indigenous Peoples Alliance of Nusantara (AMAN) at the first congress of indigenous peoples in March 1999. Since then, AMAN has embarked on an open struggle to realize the recognition and protection of the rights of indigenous peoples. AMAN's struggle is a struggle for social justice. AMAN, also, carries the struggle for citizenship rights of indigenous peoples within NKRI (the Unitary State of the Republic of Indonesia) [2]. The combination of the struggle for social justice and citizenship is closely linked to state control through the denial of the existence of indigenous peoples and the deprivation of land rights, natural resources, and the area of governance as well as the living space of indigenous peoples [2].

Jemie S. Davidson and David Hanley mentioned there are at least four factors for the revival of indigenous peoples' movements in Indonesia. First, it is a contribution to the development of discourse and encouragement from 
international organizations. Second, the pressure and oppression factors under Orde Baru. Third, the openness factor after Orde Baru Fourth, the ideological legacy of the traditional law thinkers of the colonial period [3]. The revival of indigenous peoples' movements in Indonesia today must be linked to how to place indigenous peoples along with traditional rights within the framework of a multicultural nation state. In other words, the challenge is to place indigenous peoples within the framework of citizenship. This article discussed the struggle for citizenship and collective identity among indigenous peoples in Indonesia.

\section{METHOD}

This study is theoretical using literature review method based on literature and combined with bibliographic research that focuses on the ideas contained in the theory. This research was conducted by using legal materials with doctrinal legal (normative) approach. Primary legal materials include: Indonesia Constitution UUD 1945, Law on Regional Government, Village Law, Human Rights Law Forestry Law, Environmental Protection and Management Act, Plantation Law, The Law on the Management of Coastal Areas and Small Islands, Law on Basic Regulations on Agrarian Principles, Land Acquisition Law, Social Welfare Act, Presidential Regulation no. 186/2014. The analysis uses normative analysis by conducting a review of Article 18B paragraph (2), and Article 28I paragraph (3) and the background of the formulation of the article in amendment III. Reviewing the legal structure in the form of laws, related to the juridical meaning of the recognition and respect for customary law communities. Then the content analysis (content analysis) is carried out on the content of the material in the articles from various sources of formal law by distinguishing between the material content that is norm imperative (primary rule) and facultative norms (condary rules) with a view to differentiating which articles support and negate the rights of indigenous people.

\section{RESULT AND DISCUSSION}

The current urgent need of indigenous peoples is how to place indigenous peoples and their traditional rights within the framework of a multicultural nation-state. In other words, the challenge is to place indigenous peoples within the framework of citizenship. Indigenous peoples have, so far, struggled to gain recognition as citizens and their rights. However, it is not an easy effort.

The issue begins with the debate about the terms and definitions of indigenous peoples which are still ongoing. There are various terms used from the terms of indigenous peoples, indigenous and tribal peoples, customary law community units, traditional communities, remote indigenous communities, and remote indigenous peoples. The variety of terms and definitions is supported by different agencies and different approaches in envisaging at indigenous peoples. It shows that talking about indigenous peoples is actually discussing the contestation of concepts, legislation, and sectoral agencies that deal with indigenous peoples.
TABLE I. The SCOPES AND Dimensions That Contribute

\begin{tabular}{|c|c|c|}
\hline Substance & Institution & Dimensions \\
\hline $\begin{array}{l}\text { Article 18B verse (3) } \\
\text { UUD 1945, Law on } \\
\text { Regional Government, } \\
\text { Village Law }\end{array}$ & $\begin{array}{l}\text { Ministry of Home } \\
\text { Affairs, Ministry of } \\
\text { Village }\end{array}$ & $\begin{array}{l}\text { Governance and } \\
\text { Community } \\
\text { Empowerment }\end{array}$ \\
\hline $\begin{array}{l}\text { Article 28I verse (3) } \\
\text { UUD 1945, Human } \\
\text { rights Law }\end{array}$ & $\begin{array}{l}\text { Ministry of Justice and } \\
\text { Human Rights, } \\
\text { National Commission } \\
\text { on Human Rights }\end{array}$ & Human Rights \\
\hline $\begin{array}{l}\text { Article } 32 \\
\text { UUD } 1945\end{array}$ & $\begin{array}{l}\text { Ministry of Tourism } \\
\text { and Creative Economy }\end{array}$ & Culture \\
\hline $\begin{array}{ll}\text { Forestry } & \text { Law, } \\
\text { Environmental } & \\
\text { Protection } & \text { and } \\
\text { Management Act } & \\
\end{array}$ & $\begin{array}{lr}\text { Ministry } & \text { of } \\
\text { Environment } & \text { and } \\
\text { Forestry } & \end{array}$ & $\begin{array}{l}\text { The existence of } \\
\text { Indigenous Peoples }\end{array}$ \\
\hline Plantation Law & $\begin{array}{l}\text { Directorate General of } \\
\text { Plantation, Ministry of } \\
\text { Agriculture }\end{array}$ & $\begin{array}{l}\text { Land compensation } \\
\text { for indigenous } \\
\text { peoples }\end{array}$ \\
\hline $\begin{array}{l}\text { The Law on the } \\
\text { Management } \\
\text { Coastal Areas and } \\
\text { Small Islands }\end{array}$ & $\begin{array}{l}\text { Marine and Fisheries } \\
\text { Ministry }\end{array}$ & $\begin{array}{l}\text { Management of } \\
\text { coastal areas and } \\
\text { small islands }\end{array}$ \\
\hline $\begin{array}{l}\text { Law on } \\
\text { Regulations } \\
\text { Agrarian Pric on } \\
\text { Land Acquisition Law }\end{array}$ & National Land Agency & $\begin{array}{l}\text { Indigenous peoples } \\
\text { relations with the } \\
\text { land }\end{array}$ \\
\hline $\begin{array}{l}\text { Social Welfare Act, } \\
\text { Presidential Regulation } \\
\text { no. 186/2014 }\end{array}$ & $\begin{array}{l}\text { Ministry of Social } \\
\text { Affairs }\end{array}$ & $\begin{array}{l}\text { Access to basic } \\
\text { services }\end{array}$ \\
\hline
\end{tabular}

Among the various laws and regulations are not aligned with each other, resulting in confusion of concepts and norms that have implications for confusion in assessing who is meant by indigenous peoples.

Next issue is about recognises the exixtence of Indonesian indigenous peoples. Normatively Indonesia still recognises the exixtence of Indonesian indigenous peoples as evidenced by the wording of the Indonesian 1945 Constitution Article 18B (2). The current legal framework also determines that indigenous peoples' existence must meet a number of requirements. Article 18B verse (2) of the UUD 1945 determines that the existence of indigenous peoples shall meet (a) as long as it is alive; (b) in accordance with the times; (c) in accordance with the NKRI principle; and (d) further stipulated by law. Article 18B verse (2) of the UUD 1945 becomes the constitutional basis of "conditional recognition" on the existence of indigenous peoples. Such conditional recognition is based on excessive suspicion on indigenous and tribal peoples. On the one hand, the state wants to give recognition, but on the other hand, the state suspects these customary rights may disrupt the so-called "national interest" which is sometimes interpreted as the grand opening of plantations and forests". The national interest should be interpreted as the interest of citizens to empower to manage their own resources. Hence, the national interest must be translated as the vision and mission of the government to do development from the periphery area, namely the development of the group that has been marginalized [4].

According to Bedner and Huis, the recognition is unspecific and conditional: it is vague about what rights refers to, whether a community that is lo longer 'traditional' loses its specific rights, and whether these rights remain protected if 
they are out of tune with 'altered time and culture' and 'national interest' and 'the State's interest' [5]. These norms can be concluded to be rubber norms which have diverse meanings and, consequently, the State can simply interpret them as it pleases to suit.

The arrangement of indigenous peoples to date has also spread in various laws and regulations. Characteristics of existing legislation are sectoral, contestation. From a number of legislation on indigenous peoples, it can be seen that the situation of irregularity that raises many interpretations about the position of indigenous peoples and their social units. It, ultimately, becomes an obstacle to the fulfillment of the constitutional rights of indigenous peoples. Therefore, the regulation on the unity of indigenous peoples needs to be regulated in a special law. President Joko Widodo included the importance of the Bill on the Recognition and Protection of Indigenous People's Rights in one of the points promised in the Mission and Vision known as Nawacita. Even President Susilo Bambang Yudhoyono has previously promised to prepare a special law on customary law community as mandated by Article 18B verse (2) of UUD 1945 in the Commemoration of World Indigenous Day International Day 2006. However, the fact shows that the law has not materialized even though the initiative has been for a long time. In fact, the drafting of the Bill on Indigenous Peoples is at least important for two main reasons: First, to overcome the problems faced by indigenous peoples in defending, fighting for, and restoring their rights seized by the company or by the government. Second, the regulation that governs the society, till today, has not been adequate [6].

Even the recognition of indigenous peoples' existence should be done in the form of local legal products. So far, there are three operational provisions regarding the recognition of the existence and rights of indigenous peoples, especially on land and forest, namely:

1. Ministerial Regulation No. 52 of 2014 on Guidelines for the Recognition and Protection of Indigenous and Tribal Peoples

2. Ministerial Regulation LHK No. 32 of 2015 on Right Forests

3. Ministerial Regulation ATR / BPN No. 10 of 2016 on Procedures for Determination of Communal Land Rights on Indigenous People's Land in a Specified Area.

These three operational rules require that the establishment and confirmation of indigenous peoples' presence be made in the form of local legal products, namely local regulations or regional head decisions. This form of recognition is certainly burdensome for indigenous peoples, because to exist as legal subjects they must fulfill formal procedures that are intricately administrative and political. This has shifted the position of indigenous peoples who were formerly natural law subjects that existed long before the state of the Republic of Indonesia even existed, became the subject of formal law whose existence was strongly determined by the existence of official documents. In fact, as a legal society (rechtgemeenschaap), indigenous and tribal peoples are different legal subjects with natural persons (naturalijkpersoon) and legal entities (rechtpersoon) which are known in legal studies. As a legal subject, indigenous and tribal peoples have capabilities, as persons with rights and obligations in legal traffic. While the legal community (rechtgemeenschaap) is a collection of people who naturally form a community, both based on territorial (territorial) and genealogical (genealogical). Its capacity and responsibilities as legal subjects were not established by the government, but acquired social legitimacy even before the Republic of Indonesia was founded.

So far, the concept of a nation state puts individuals as the basis of citizenship. Individual citizenship process goes mainly through education, so that new citizens are formed as subjects within the framework of the nation state. However, it is not the case with indigenous communities. They experience the process of coercion and deprivation of the living area. Land grabbing and discrimination experienced by indigenous peoples has been an obstacle for indigenous peoples. The problems experienced by indigenous peoples so far have made a very strong impression that they are not citizens who have rights that have been guaranteed in the constitution. Therefore, resolution of conflicts over land as well as discontinuation of discrimination against indigenous peoples is an important factor for indigenous peoples. The legal effort to place indigenous peoples as citizens with special status has actually begun to appear in a number of legislation, but the problem appeared is the absence of operational rules for the fulfillment of the rights of indigenous peoples. For example, everything related to land rights, customary forest rights, coastal water rights, educational rights and others do not have operational regulations.

Indigenous peoples' citizenship should be placed in the context of multicultural citizenship where the subjects are not only individuals, but also indigenous communities that have equal human rights with individuals. This is in line with the concept of self-determination, which is one of the most important principles in the revival of the international indigenous movement, which holds the view that those who know best for the survival of indigenous peoples are indigenous peoples themselves. Therefore, the government or other parties who want to run the development program should respect the rights of indigenous peoples through the Free and Prior Informed Concent (FPIC) procedure. Free and Prior Informed Consent (FPIC) is a process that allows indigenous peoples and/or local communities to exercise their fundamental rights to state whether they agree or disagree with an activity, project or policy to be implemented in the living spaces of the community and potentially affecting the land, the region, the resources, and the livelihoods of the people. FPIC instruments are used as rights of indigenous peoples and/or local communities to obtain information (informed), prior to (Prior) a development program or project implemented within their customary territory or manage it, and on the basis of that information, they freely without pressure (Free) agree (Consent) or reject.

The above description shows that the struggle to change the official categorization of a population group by the state is the main concern of the fight against injustice. Citing the argument of Alan Hunt, the leader of the critical legal studies, that "rights are manifested and shaped by and through struggle" [7], confirmed by the view of Charles Tilly, a prominent 
sociologist, that the social movement's struggle for transforming injustice always begins with a change of category imposed on the discriminated.

\section{Tilly wrote:}

"Prolonged injustice between categories arises because people who control access to the value-producing resources solve organizational problems through categorization. Deliberately or unintentionally, people are setting up systems that involve restrictions, excommunication, and control." [8].

The main struggle of a group of social movements is to change the categorization of a group championed from the statuses that discriminate against them into a new status. Campaigns and policy advocacy from social movement groups will enter a new phase when government agencies change the categorization of a group of citizens they strive for.

Thus, the migration of indigenous peoples' categories of citizenship should be placed in the context of multicultural citizenship and this is by no means a trivial matter. According to Hannah Arendt, (status) of citizenship (a group or individual) is a necessary condition for all rights persons. Citizenship is the right to have rights. It is the ultimate right of the right to recognition, entry-in and membership in a particular unit of political society.

In this case, the authors contrast the status of fully recognized citizens as persons of rights and status as citizens who are discriminated against and denied their existence as persons with rights. As long as the citizenship status of a community group is not actually recognized by the institutional practice of government agencies, discrimination against it will continue.

\section{CONCLUSION}

People living in group of indigenous peoples have not been acknowledged as citizens entirely on their status as persons with rights, separate legal subjects, and owners of their customary territories. Violence and discrimination are still being experienced by indigenous peoples. It indicates that the indigenous peoples' struggle for inclusive citizenship, which requires the Government of Indonesia to legally and actually recognize and respect the status of indigenous people's citizenship in the Unitary State of the Republic of Indonesia is not yet over. It takes a pluralist approach that sees indigenous peoples as a diversity that must be maintained, so that indigenous peoples need to be guaranteed their basic rights independently to determine choices for the development of their respective communities. Therefore, the future discourse on citizenship in Indonesia is not only seen from the individual citizens, but also communal citizens who are members of indigenous communities. Indigenous citizenship also needs to place indigenous peoples' relations with the land and their source of life as entitlement, so that the subjective identity of indigenous peoples is not only seen from the community but integral to its territory and living space.

Therefore, the formation of special law on indigenous peoples is very important to address the problems faced by the community in the field (social aspect) and also to overcome the problem of legal misconception about the legal aspect that has been causing uncertainty and confusion that ultimately inhibit the fulfillment the constitutional rights of indigenous peoples as Indonesian citizens.

\section{REFERENCES}

[1] Polanyi, K. The Great Transformation: The Political and Economic Origins of Our Time. Boston: Beacon Press. 1957.

[2] Rachman, N.F. "Masyarakat Adat dan Perjuangan TanahAirnya.’Kompas 11 Juni. 2012.

[3] Davidson, Jamie S., David Hanley, \& Sandra Moniaga (ed). Adat dalam Politik Indonesia (Indonesian trans. E.O. Kleden\& Nina D). Jakarta: Yayasan Pustaka Obor Indonesia \& KITLV-Jakarta. 2010.

[4] Arizona, Yance and Erasmus Cahyadi, 'The revival of indigenous peoples: Contestation over a special legislation on MasyarakatAdat,' dalam Hauser-Schäublin, Brigitta (edt), Indigenous peoples and customary law: From discrimination to empowerment, Gottingen University, Germany. 2013.

[5] Bedner, A \& Huis, S.v. 'The Return of the Native in Indonesiaa Law'.

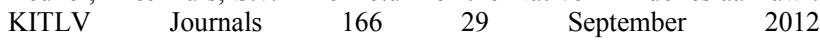
https://openaccess.leidenunivnl/bitstream/handle/1887/18073/Bedner\%2 0A.W.\%20and $\% 20$ S.C. $\% 20$ van $\% 20$ Huis. $\% 20$ The $\% 20$ return $\% 20$ of $\% 20$ the $\% 20$ native $\% 20$ in $\% 20$ indonesian $\% 20$ la w.pdf 165. 2010.

[6] Arizona, Yance. "Memahami Masyarakat Adat :Pendekatan Evolusionis dan Pluralis."Makalah disampaikan dalam Focus Group Discussion (FGD) Perlindungan Konstitusional Masyarakat Hukum Adat yang diselenggarakan oleh Pusat P4TIK Mahkamah Konstitusi, Jakarta, 21 Juli 2016. 2016

[7] Hunt, A. "Rights and Social Movements: Counter-Hegemonic Strategies." Journal of Law and Society 17 (3). 1990.

[8] Tilly, C. Durable Inequality. Berkeley: University of California Press. 1998. 